\title{
THE NEED TO REFORM THE HOSPITAL PAYMENT SYSTEM IN INDONESIA
}

\author{
Nur Hidayah ${ }^{1 *}$, Arlina Dewi ${ }^{1}$, OU Jen-ho² and Qurratul Aini ${ }^{1}$ \\ ${ }^{1}$ Hospital Management, Universitas Muhammadiyah Yogyakarta, Jl. Brawijaya, Kasihan, Bantul, Yogyakarta, 55183, \\ Indonesia, \\ ${ }^{2}$ Department of Finance, College of Management, Asia University Taiwan, 500, LIOUFENG rd., Wufeng Dist., Taichung \\ City 41354, Taiwan
}

*Corresponding author: Nur Hidayah

Email: nurhidayah@umy.ac.id

\begin{abstract}
One of the crucial health policies in hospitals is about physician payment methods. Indonesia had implemented the National Health Assurance since 2014 to achieve Universal Health Coverage by 2019. Most of hospital revenue is packaging from the National Health Insurance Agent (called BPJS). However, Fee-for-service (FFS) payment method is still dominant in many hospitals. How can hospitals make policy to rearrange the payment method to attain hospital performance? The purpose of this research is to analyze the payment system that can improve employee satisfaction and performances. Mix method was used to collect data and make an interpretation. Data collected from 185 respondents and four key informants. The result showed that the policy in private and public hospitals in Indonesia of the physician payment is diverse. Most of the hospitals use the pure FFS for self-employee physicians (part timer employee). For full time employee, they applied FFS mixed with salary, or remuneration. To improve employee satisfaction and performance, the hospitals should make a policy to link the FFS to pay for performances. The hospital should make the tailoring program by involving the physician in a designing method of the hospital remuneration.
\end{abstract}

Keyword: Physician payment, method, remuneration, hospital performance

\section{INTRODUCTION}

The third-largest expense in healthcare is the physician remuneration. The method of remuneration design is a priority in healthcare policy ${ }^{1}$. Remuneration is financial benefits as the total revenue of employee personally that may contain monetary rewards decided based on different rules in the organization. For instance, the total remuneration of a physician may count payment of a fee-for-services, fee-forperformance, a salary, and shared financial risk. The remuneration, therefore, is a total income that combines the package of payments that compose an individual's total revenue ${ }^{2}$. To improve the quality of health care, the Institute of Medicine has recommended pay-for- performance as an incentive for physicians ${ }^{3}$. In Indonesia, pay-forperformance has been a part of the remuneration system in public hospitals owned by the central government. Other hospitals, namely private hospitals, and public hospitals owned by local governments do not have to follow the central government in implementing the remuneration. A study at a public hospital in Jakarta, Indonesia, the pilot project of the implementation of a remuneration system, showed that the satisfaction level of functional medical staff and nurses was only $28.8 \%$. The remuneration does not affect hospital performance ${ }^{4}$. This research result was not intended. It was not in accordance with the objective of pay-for-performance. There have been health care providers that adopt pay-forperformance to improve health care quality. On the contrary, most healthcare payment systems still use the approach of a fee-for-service. The feefor-service model should be adjusted to pay-forperformance. When health care providers produce higher-quality care, then they get higher payments, as the reward ${ }^{5}$. The National Commission on Physician Payment Reform of United States recommended new payment methods for physicians; which will eventually improve the outcomes of patients and control health care costs ${ }^{6}$.

There are four models of remuneration that were paid for Physicians, in a variety of ways ${ }^{7}$ :

1. Pure Fee-for-Service. Physician as a selfemployed that bills for every service done, it is called Free-for-Service (FFS).

2. FFS plus bonus, if the performance met the target.

3. APP (Alternatives Payment Plan). It is remuneration for clinical care and numbers of people (community) based on physician targets. APP is also offered to some medical specialist.

4. Salary based payment.

In Indonesia, the components of remuneration are fee-for-position (P1), fee-for-performance (P2), and fee-for-people (P3) ${ }^{8}$. The P1, P2, and P3 structure of the remuneration are compulsory to be implemented in public service agency Hospital. There are steps to formulate the remuneration. First, set the job value and job class based on the result of job analyze (8) and job evaluation (9) to calculate the pay-for-position. After that, identify the period of work, education level, and the position or job in the hospital organization. The 
other name of the pay-for position is the salary that is paid to the employee every month in the form of a fixed payment. Second, do performance evaluation of the individual employee and the work department or unit. Identify the Individual Performance Indicators and the Unit Performance Indicators. Pay-for-Performance is a payment based on the performances of the employee and the work unit. The performances sometimes increase or decrease. So, the number of pay-forperformances are not fixed, depend on the performances. Third, determine Pay-for-People based on individual need and characteristic. It can be in the form of health insurance premium, a specific payment to celebrate religion special days (holidays), etc.

Pay-for-performance as the payment approach has been implemented widely with the goals to improve the healthcare and services quality in effective and efficient ways. Werner et al. had examined the effect of the payment for performance in 260 hospitals. He suggested that tailoring programs for pay-for-performance in different situation could have the best effect on improving healthcare quality ${ }^{9}$. Remuneration for the specialist is at the most.

The physicians, particularly medical specialists, are the crucial health care providers in a hospital. The remuneration payment for specialists is the largest compared to other human resources in the hospital, except the director of the hospital. The physicians should provide the best service to patients, based on their professional standards, so as compensation, the physicians prefer FFS than another payment system. However, the physicians should give lower cost to the patients who cannot afford to pay. The physicians give a lower cost for their services to patients who can't afford to pay. Alternatively, they exempt from service fees as charities, that compensated by withdrawing payments from wealthy patients. FFS motivates the physicians to provide more services and services that are not obligatory to maximize their income. The FFS method of payment has been implemented for a long time in many countries, and until now, FFS is still dominant ${ }^{10}$. Another research also found that most of the medical specialists are still tend to use FFS. They tend to manage more services while reducing the duration of service to get more incentives ${ }^{11}$. Refer to Barro and Beaulieu 2003, an FFS of payment system makes the medical specialists more productive, because they are rewarded as expected. In the country, where both FFS and remuneration system is implemented together side by side, FFS earn more than the salaried physician ${ }^{11}$. In the future, the fee-for-service model of payment is likely still dominated rather than the fixed payment model, although the national policy has forced to shift toward the fixed payment based on the remuneration model. So, it is urged to prepare recalculated fee-for-service payment which suitable to improve quality of services, optimize and get more effective cost, and avoid any misuses and overuse cares ${ }^{12}$.

A quality-based compensation model has been developed by the U.S. Healthcare, for primary care, specialist, physicians, and hospitals. Additional compensation is only provided based on quality and cost-effectiveness achievement. This model is contrasted with FFS models that clearly do not encourage the improvement in performance. This model aligns with the incentives of US Healthcare purchasers, participating providers, and members to show the high quality, cost-effective care which maximizes the patient outcomes. 13. Logically, pay for performance system is to pay physicians and hospitals just based on how well their patients are, rather than on the number of medical services done. Pay for performance is also recognized as a value-based purchasing that meant encouraging physician to consider the welfare of patients by discouraging spending on unnecessary cares ${ }^{14}$.

Mendes et al. ${ }^{15}$ show that in both private and public hospitals, analyzing remuneration is important as a management and control instrument. There was evidence of conflicts between the administrative area, and the medical area can prevent the hospital management process. Remuneration also influences the decision-making process and individual' behavior 16 .

The problem in Indonesia is the hospital revenue in the package of Indonesia Case-Based Groups (INACBGs) ${ }^{17}$ since the implementation of National Health Insurance, in 2014, while payments to specialist physicians still use fee-for-service. INACBGs is a pattern payment for health service rates at hospitals as continued health facilities. There are two hospital payment methods used, namely, retrospective and prospective payment methods. The retrospective payment method is a payment method conducted on health services provided to patients based on each service activity provided, the more health services provided, the greater the cost paid. An example of a retrospective payment pattern is Fee-for-Services (FFS). Prospective payment method is a payment method done for health services whose amount is already known before health services are given. Examples of prospective payments are global budget, perdiem, capitation, and case-based payment. Capitation is a payment for primary health services, and INA-CBGs is case-based payment for hospitals.

The problem is: how to rearrange the payment system for the physicians and other employees to create balance system between the value for the hospital as an organization, the employees; especially medical specialists, and the patients as customers. Furthermore, it examined how the hospital remuneration system can increase employee performance and satisfaction. The 
purpose of this research is to analyze the payment system in a hospital that can improve employee satisfaction and performances.

\section{METHODS}

The research method in this study is a mix-method approach with a cross-sectional design. The population was the human resource owned by public and private hospitals in Indonesia, particularly those involved in the payment system. This study employed purposive sampling technique resulting a total of 186 samples from 300 questioners. The steps in collecting data were; first, quantitative data was collected by providing questionnaires to respondents. The respondent answered the questioner in the form of selfassessment. The respondents were from Hospital Functional Medical Staffs, nurses, and administrative officers. However not all of them filled the questionnaire completely. After quantitative data were analyzed, the second step was the qualitative data collected through interviews from four key informants. The informants were selected with reference to the principle of conformity as it relates to substance and according to the research needs. Key informants were two directors, a financial manager, and a human resource manager of private hospitals in West Java, Central Java, and East Java, Indonesia whose responsible, involved in payment system decision making and experts in remuneration system implementation. The researcher directly met and interviewed the informants.

\section{Operational Definitions:}

1. Human resources in a hospital are people who work in the hospital that comprises of health workers and non-health workers. Health workers such as physicians or medical doctors (generals and specialists), nurses, midwives, pharmacists, laboratory specialists and technicians, nutritionists, radiologists, etcetera who certified by health education institutions and have authorities in health care. Non-health workers like management experts, accountants, information system experts, engineers, etc. who graduated from non-health education institutions.

2. The payment system is a system of payment used in a hospital to pay the human resources as compensation of their works in the form of money.

3. Remuneration is the payment system used in a hospital that comprise of pay-for-position, pay-for-performance, and pay-for-people.

4. Fee-for-service is payment based on the health care and service given by the providers in the hospital for patients.

5. INA-CBGs is a package payment from National Health Insurance Agent based on the case of disease (diagnoses and procedure of treatments).

Types of the questions for interview were what kind of payment system which implements in your hospital? Why have the decision-makers chosen the kind of payment system to implement in the hospital? What was the problem in implementing the remuneration system in your hospital? How did the hospital solve the problems? Did the remuneration system increase employee satisfaction and performance? The remuneration system is an independent variable that effected on two dependent variables, namely employee satisfaction and employee performance. If the remuneration system be improved, then the employee satisfaction and employee performance will be increase.

\section{RESULTS}

The characteristics of respondents of the filed out questioner are followed: The age of the respondents between 20 - 50 years old was $93.7 \%$; the rest was more than 50 years old. According to the duration of work, $65.3 \%$ of the respondents have worked less than ten years, while the most significant number was new employees. They have worked for one up to four years, which was $39.4 \%$. So, they had known, experienced, and had been involved in the hospital payment system.

The various education level of respondents was; (a) Diploma 4 (b) Bachelor and profession of health, (c) Master degree and (d) Medical specialist. All respondents were 185 persons, but not all respondents answer the questions thoroughly. The board of directors was managerial positions that often held by general physicians and specialists. The managerial job was the most jobs of the respondents (63.3\%). They were decision-makers in managerial issues, including the payment system in the hospitals, of course, by considering the input of medical specialists as the main provider of health service offered by hospitals to the public.

The most frequent job positions were managerial positions, which consist of the chief directors, directors, managers, section heads, head nurses, heads of medical services, heads of non-medical services, and many others. In the hospital, there are managerial job positions and functional job positions. Functional job positions in accordance with their profession, managerial positions may be held by employees with functional job positions such as directors and directors served by physicians or specialists. General physicians $60 \%$ and specialists $60 \%$ held managerial Job Position; nurses who hold the managerial job, as dean of the inpatient room, or the other managerial job. Most of them are decision-makers in the hospital payment systems.

Most respondents are the permanent employee $(85.1 \%)$, and the rest is a temporary employee. This employment status determines the salary from the hospitals. For the Indonesian remuneration system, one of the components of remuneration is fee-forposition that is known as salary. The position is determined by education level, experience, 
duration of work, and the job position. Quantitative data were analyzed using SPSS to know the frequencies of the pattern of a payment system in the hospital and the rank of obstacles to implementing the remuneration system. Cross tabulation was employed to analyze the relation of the profession and payment system, satisfaction and payment system, payment system, and performance.

\section{Table 1: Payment Systems in Hospitals}

\begin{tabular}{lcc}
\hline Payment System & Frequency & Valid \% \\
\hline Fee-for-Service (FFS) & 4 & 2.3 \\
FFS and Salary & 101 & 57.4 \\
FFS and Remuneration & 38 & 21.6 \\
Remuneration & 10 & 5.7 \\
Profit-Sharing & 3 & 1.7 \\
Other & 20 & 11.4 \\
Total & 176 & 100.0 \\
\hline
\end{tabular}

In Table 1, in hospitals where the respondents worked, FFS payment system was still dominant. There was $81.3 \%$ payment system used FFS, pure, and mix with salary and remuneration. FFS and Salary were the most dominant payment, then followed by FFS and remuneration. Pure Remuneration payment and mix remuneration and
FFS was $27.3 \%$ of hospitals.

There were obstacles in the implementation of remuneration that show in Table 2.

\section{Table 2: Obstacles in the Implementation of Remuneration}

\begin{tabular}{lcc}
\hline \multicolumn{1}{c}{ Description } & Frequency & $\begin{array}{c}\text { Valid } \\
\%\end{array}$ \\
\hline BPJS payment is late & 30 & 20.8 \\
the hospital is not ready & 51 & 35.4 \\
Lack of socialization & 11 & 7.6 \\
salary under the & 6 & 4.2 \\
$\begin{array}{l}\text { standard } \\
\text { not on time }\end{array}$ & 21 & 14.6 \\
$\begin{array}{l}\text { FFS culture is still } \\
\text { dominant }\end{array}$ & 25 & 17.4 \\
Total & 144 & 100.0 \\
\hline
\end{tabular}

In Table 2, most respondents stated that the hospital is not ready to implement the remuneration. The second-order, BPJS payment is late, the third order FFS culture is still dominant, the fourth order, the payment from BPJS not on time, the fifth-order is lack of socialization, and the last order is salary under the standard.

Table 3: Profession*Payment System in the Hospitals

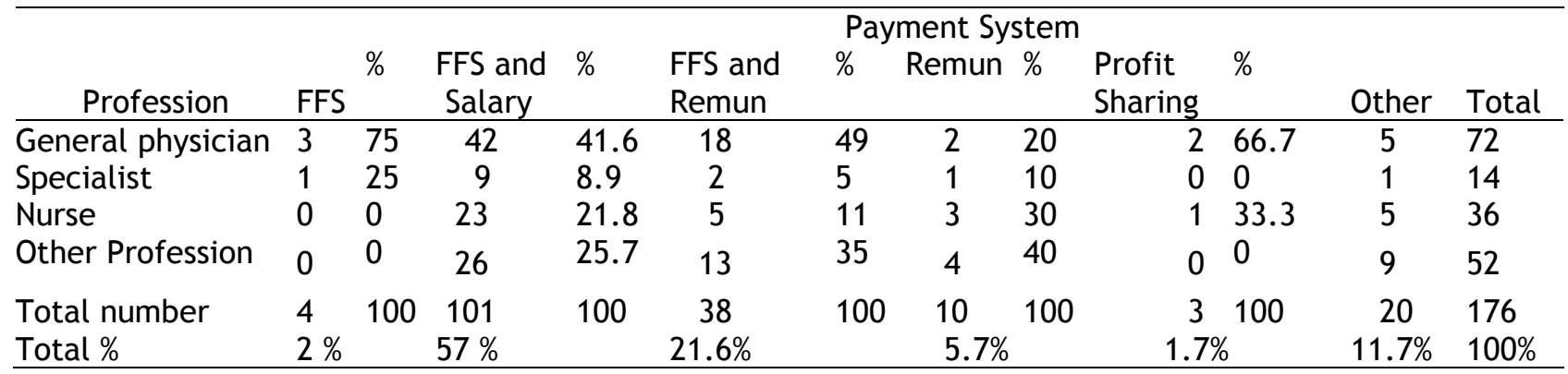

Table 3 show the result of cross-tabulation between profession and payment system in the hospitals. Chi-Square 15.105 was not significant with $\mathrm{p}$-value was $0.444>0.05$. However, in terms of descriptive, it can be described that the hospitals use a pure FFS payment system to a specialist physician and general practitioners. Manually calculation based on horizontal total number raw, the pure FFS is $2 \%$, the FFS and salary is $57 \%$, FFS and Remuneration $21,6 \%$, pure remuneration is $5,7 \%$, profit sharing is $1,7 \%$, and other payment system is $11,7 \%$.

Table 4: Satisfaction and Payment System in The Hospital
In table 4 stated that satisfied respondent is greater than dissatisfied respondent with the payment system applied by the hospital. Almost 50 percent of the respondents were physicians.

\section{Table 5: Effect Payment System on} Performance

Effect Payment System on Performance Description $\begin{array}{cc}\text { Frequency } & \text { Valid } \\ \text { Percent }\end{array}$

yes, effected 55.2

no effect $\quad 74 \quad 44.8$

Total 165

\begin{tabular}{lcc}
\hline Description & Frequency & Valid Percent \\
\hline Satisfied & 105 & 63.6 \\
Dissatisfied & 60 & 36.4 \\
Total & 165 & 100.0 \\
\hline
\end{tabular}


According to respondents, $55.2 \%$ stated that the payment system effect on the performance. In Table 6, more respondents satisfied with the payment system, even though there were respondents who were not satisfied with the payment system. With Pearson Chie-Square 7,662 significant at $0.006<0.05$. Table 7 shows that satisfaction affects performance, but there was deference statement between the satisfied respondent and the dissatisfy respondent. Most of the dissatisfied respondent stated that satisfaction effect on performance.

Table 6: Effect Payment System on Satisfaction

\begin{tabular}{lcc}
\hline & Effect Payment System on Satisfaction & \\
\hline Description & Frequency & Valid Percent \\
Satisfied & 105 & 63.6 \\
dissatisfied & 60 & 36.4 \\
Total & 165 & 100.0 \\
\hline
\end{tabular}

Table 7: Cross Tabulation Satisfaction of Payment System and Performance

\begin{tabular}{llcccccc}
\hline Description & & \multicolumn{3}{c}{ Effect } & on performance & Total & $\%$ \\
\cline { 3 - 6 } & & yes, affected & $\%$ & no effect & $\%$ & & \\
Satisfaction & Satisfied & 49 & 47 & 55 & 53 & 104 & 100 \\
Total & Dissatisfied & 41 & 69 & 18 & 31 & 59 & 100 \\
& & 90 & 55 & 73 & 45 & 163 & 100 \\
\hline
\end{tabular}

The interview results supported the quantitative data as follow:

The hospitals chose the mix-method payment system between FFS and remuneration. The hospitals had to provide a reserve budget to pay a fee-for-service to a medical specialist. The hospitals that cooperated with National Health Insurance Agent (Badan Penyelenggara Jaminan Sosial Kesehatan or BPJS) claimed their health service in the form of case-based group documents every month. After the BPJS verified the claim documents, they would make the decision, agreed to be paid or disagreed with being paid because of some problems. The problem of the claim document returned to the hospital to be repaired according to the mistake, or there may be data that was lacking. The delay payment was caused by deferent perception between the hospital administrators and the BPJS, there was no specific guideline of new

\section{DISCUSSION}

The payment system for hospital staff consists of 1) FFS, 2) FFS and Salary, 3) FFS and Remuneration, 4) Remuneration, 5) profit sharing, and others. The Fee-for-Service Payment System is still dominant as a pure FFS and mixed with salary or remuneration is $81.3 \%$. The dominant payment system by FFS is in accordance with the explanation of Ikegami that the reason of the physicians prefer FFS is that the payment of physicians should be balanced with their duty of cases, and many other problems. ${ }^{18}$ The payment from BPJS is based on INA-CBGs tariff. In public hospitals owned by the center government (Badan Layanan Umum /BLU or Public Service Agency) have implemented pure remuneration. Public hospitals own by local government (Badan Layanan Umum Daerah or BLUD) depend on local government policy and private hospitals depend on hospital management policy. They can modify the remuneration system of the public hospital of BLU. The government policy states that a physician can work at three hospitals or other health care provider institutions. The private hospitals' dependence on specialists is very high because the number of specialists is limited. So, FFS is still dominant. The remuneration budget was allocated to FFS for specialist first; then the rest was allocated to remuneration, namely for salaries, performance incentives, and benefits.

professionally in providing the best service to the patients. Douven et al. (2015) stated that average, $68 \%$ of physicians were paid FFS (majority). The types of remunerations were FFS and salary. The data were obtained from almost all university and individual general hospitals of Dutch Hospitals ${ }^{19}$. According to Wright (2007) in private hospitals, the specialist physicians usually paid by FFS and in public hospitals, they usually paid by salary. The specialists preferred FFS for their income and profit-maximizing in private hospitals ${ }^{20}$. 
In Indonesia, a hospital as a public service agency compulsory to implement remuneration that consists of fee-for-position or salary, a fee-forperformance (payment based on performances), and fee-for-people (additional payment based on individual characteristic).

The most hospitals did not ready to implement the remuneration because the culture of FFS was difficult to be changed. Change management should be implemented in the hospitals. How to strive a competitive advantage in a health care market, the managers face extra ordinary challenges because of rapid change in health care environment, such as adopt new technologies for medical records, a new program to improve the quality service, and employ the pay-for performance plans ${ }^{21}$.

Management of the specialist physicians is a crucial task of human resources management for a hospital. Management of human resource is one of the essential factors in improving the prosperity of an organization. Physicians are human capitals in a hospital organization. They contribute not only in the process of the development of the organization but also in winning the competition among the similar organizations surrounding. Recently a human capital is an intangible asset of the organization. Intangible is acknowledged as the most valuable asset, because of that, they must be both well administered and get proper compensation, otherwise, they can leave easily ${ }^{22}$. The organization knows that hiring expenses is much higher rather than retaining expenses. Generally, the organization knows about the phrase "Health is wealth, without proper health, a country can't make sure its prosperity." Medical doctors as physicians are the pillar of the hospitals, and consequently, without them, the hospitals are nothing ${ }^{23}$. The remuneration does not make all employee satisfied and improve hospital performances. This is supported by the previous research result ${ }^{4}$. The dissatisfied employee can trigger a conflict in a hospital. For example, conflict between doctors and the government in Pakistan happened currently because of their demand was not fulfilled by the government. Since two years ago the conflict emerges, the doctors had continued their protest against the government due to the doctor's dissatisfaction with their increasing works, and their complaints were not responded. They did not treat patients as should be. The doctor's turnover also increased 24 .

When the satisfaction level is low and performance is high, the satisfaction has no effect on performance. In the country, where both FFS and remuneration system are implemented together side by side, FFS earn more than the salaried physician ${ }^{11}$. Fee-for-Service is not fixed income, but variable income based on the number of services was provided by the physician. For other professions, research in Malaysia found that instructors with higher income are more satisfied if they got fixed income (with a commission or not) ${ }^{25}$. The remuneration that did not satisfy the medical staff and nurses ${ }^{4}$ consist of fixed payment (salary), and variable payment that are the fee-for-performance and fee-for-people. In Indonesia, physicians have three places for their practices, different with other professions. Because of that, the physician payment should be reviewed to solve the problem.

Another study on FFS models, the result stated that FFS clearly did not encourage the improvement in performance. This model did not align with the incentives of US Healthcare purchasers, participating providers, and members to show the high quality, cost-effective care which maximizes the patient outcomes ${ }^{13}$ Werner, et al. suggested that tailoring programs for "Payfor-performance" hospital in different situations could have the best effect on improving health care quality 9. Pay for performance is also recognized as a value-based purchasing that is meant for encouraging physician to consider the welfare of patients to reduce spending on unnecessary care ${ }^{14}$.

The research results of the Netherlands Ministry of Health, Welfare and Sport support the results of this study, that in six European countries namely Netherlands, Denmark, Belgium, France, United Kingdom and Germany, the physician payment system is a mixture of FFS and salary. In government hospitals and educational hospitals all specialist physicians are paid with the salary system, but they also work alone with FFS payments, either open their own practice or work with self-employed (FFS) in private hospitals. So it is not clear the difference between a salary paid specialist and an FFS paid specialist ${ }^{26}$.

The specialist physician working on self-employed is essential FFS. To gain greater incentives, specialists may add more services per hour and reducing the time of service. Specialist physicians who work with payroll systems cannot do so. Consequently they cannot get an incentive ${ }^{26}$. In addition, they work in a hospital that earns salary while work as a Self-Employee based on FFS. It is also happen in Indonesia, a physician of both general practitioners and specialist physicians, their physician's registration certificates can be used in 3 hospitals, so when they work in hospital public service agencies that implement remuneration system, they also work in other hospitals with FFS payments.

There is a different understanding of the term remuneration model, according to the Ministry of Health of Republic of Indonesia with The National Commission on Physician Payment Reform ${ }^{7}$. The remuneration model in Indonesia consists of Feefor-Potion, Fee-for-Performance, and Fee-forPeople, while according to The National 
Commission on Physician Payment Reform, the remuneration consists of several models, there are FFS, Enhanced FFS (FFS plus bonus), Alternative Payment Plan (APP) (for clinical work and family physicians), and salary ${ }^{7}$. APP can be a mixed model remuneration or agreement based on the results of individual negotiations.

The result of this research regarding FFS is still continuously dominant though mixed with salary or remuneration. This is in accordance with Fallon prediction in 2003, "Because fee-for-service will remain an important mode of payment into the future, even as the nation shifts toward fixedpayment models". Fallon recommended "to recalibrate the fee-for-service payment method to improve the quality of healthcare and services, to achieve more effective cost and to avoid misuse and overuse care" 7 . This is in accordance with the goal of the case-mix system applied in Indonesia by the name of INA-CBGs. In order to balance the value of hospital income in the form of INA-CBGs package, it is necessary to implement a package remuneration system as a form of payment to hospital human resources. In 2019 every Indonesian citizen must be a member of NHA to reach Universal Health Coverage ${ }^{17}$. A Casemix (case-based payment) is a prospective payment method. The definition of the case-mix system is grouping diagnosis and procedure with reference to the similar/ similar clinical features and similar/similar use of resources/maintenance costs, the grouping was done using grouper software. The case-mix system is currently used widely as the basis of the health system payments in developed and developing countries.

Most private hospitals in Indonesia still use FFS for the physicians although mixed with salary and incentive (pay-for-performances). The number of a medical specialist not in accordance with demand, so the bargaining power of specialists is very high. The research found that surgeons, internists, anesthesiologists, neurosurgeons in Thailand are estimated to face a significant shortage in the next five (5) years ${ }^{27}$. Private hospitals that need more specialists have to adjust with the preference payment by specialists. Even though, the hospitals must provide the backup budget for FFS, because most of health service payments that were provided by hospitals must be claimed to the implementing body of social health insurance that takes time about one month.

According to empirical research undertaken by Barro \& Beaulieu, in 2003, FFS is not only stimulating production, but also make more productive people. Physicians that assume they must do the best for their patients need to be rewarded properly; therefore, they choose a feefor-service position. Moreover, higher productivity can be encouraged by the fee-forservice payment schedule. In Canada, mention by OECD Health Statistics 2017, 85\% physicians (specialists exclude imaging and laboratory specialists) in private practices self-employed specialists who received FFS payment (Canadian Institute of Health Information, 2016) "If the payment system of salary physicians is changed into a fee-for-service scheme, they become more productive (Barro \& Beaulieu, 2003). The other way around is also the case: if the payment schedule of the self-employed is changed from fee-for-service to fixed payment (lump sum), then productivity decreases. If a revenue ceiling is introduced, they will not produce fewer services per hour but will work fewer hours in order to increase their leisure time" ${ }^{28}$.

Where the self-employed physician role is more dominant, it is more flexible in responding to the higher demands by adding working hours. Theoretically, more salary comes from a better performance. Countries where this investigation was done are Netherlands, Denmark, Belgium, France, United Kingdom, and Germany, are hardly any pay for performance that have been introduced. But in countries where two systems are applied, that might not be necessary, because a self-employed physician can accommodate any pressure on the system ${ }^{28}$. Fee-for-performance was not consistent from low to strong evidence effect on intermediate health outcomes and not enough evidence that pays for performance for patient outcomes. There was low-strength evident that fee-for-performance reducing hospital readmissions and patient health outcomes ${ }^{16}$.

In Indonesia where the hospital owned by a central government and local government, the physician remuneration is arranged by the government. For physicians in different categories and specialists, the level of remuneration may effect on the financial attractiveness.

Many countries have implemented the regulation to classify and standardize the remuneration for physician fees and services. The remuneration between salaried physician and self-employed physician is distinguished. However, that distinction among the countries is not clear. In many countries, a salaried physician is allowed to have private practices, and self-employed specialist may get part of their remuneration as salaries. The remuneration between general physician and other medical specialists are also distinguished, so there might be wide differences in income among medical specialists ${ }^{29}$.

\section{CONCLUSION}

A payment system in the hospital effect on employee satisfaction and employee performance. Fee for service is still dominant especially for the specialist physicians. The hospitals apply pure FFS and mix with salary or remuneration. The hospitals should improve the payment system by linking the FFF and the 
physician/employee performance, so they can improve the service quality, cost effective ness and also employee and patient satisfaction. The hospital should make the tailoring program by involving the physician in a designing method of the hospital remuneration base on the specification of the hospital organization.

\section{ACKNOWLEDGMENT}

The authors gratefully acknowledge the research grant from Universitas Muhammadiyah Yogyakarta Indonesia and Asia University Taiwan, in this collaborative research program.

\section{REFERENCES}

1 Rudmik L, Wranik D, Rudisill-Michaelsen C. Physician payment methods: a focus on quality and cost control. J Otolaryngol Head Neck Surg J Oto-Rhino-Laryngol Chir Cervico-Faciale 2014; 43: 34.

2 Buchan J, Thompson M, O'May F. Health workforce incentive and remuneration - $\mathrm{A}$ research review

https://apps.who.int/iris/bitstream/han dle/10665/69777/WHO_EIP_OSD_00.14_e ng.pdf;jsessionid=7EA27F9FA9A7445629E 1517938 CAC159?sequence $=1$.

2000.https://apps.who.int/iris/bitstream /handle/10665/69777/WHO_EIP_OSD_00. 14_eng.pdf;jsessionid=7EA27F9FA9A7445 629E1517938CAC159? sequence $=1$ (accessed 12 Jul2019).

3 Britton JR. Pay for Performance for Salaried Health Care Providers: Methodology, Challenges, and Pitfalls. Perm J 2014; 18: 78-85.

4 Soetisna TW, Ayuningtyas D, Misnaniarti M. Penerapan Sistem Remunerasi dan Kinerja Pelayanan. Kesmas Natl Public Health J 2015; 10: 17-23.

5 Mehrotra A, Damberg CL, Sorbero MES, Teleki SS. Pay for Performance in the Hospital Setting: What Is the State of the Evidence? Am J Med Qual 2009; 24: 19-28.

6 Slemmer. Our nation cannot control runaway medical spending without fundamentally changing how physicians are paid. 2013; : 24.

7 Rudmik L, Wranik D, Rudisill-Michaelsen C. Physician payment methods: a focus on quality and cost control. J Otolaryngol Head Neck Surg J Oto-Rhino-Laryngol Chir Cervico-Faciale 2014; 43: 34.

8 Kementerian Kesehatan Republik Indonesia. Pembahasan Remunerasi
Kemenkes No. 625 Tahun 2010. Scribd. 2010.https://www.scribd.com/document /324791836/Pembahasan-RemunerasiKemenkes-No-625-Tahun-2010 (accessed 9 May2018).

9 Werner RM, Kolstad JT, Stuart EA, Polsky $D$. The effect of pay-for-performance in hospitals: lessons for quality improvement. Health Aff Proj Hope 2011; 30: 690-698.

10 Ikegami N. Fee-for-Service Payment-An Evil Practice that Must be Stamped Out? । International Journal of Health Policy and Management IJHPM and 直己 池上 Academia.edu.

2015.http://www.academia.edu/106172 23/Fee-for-

Service_Payment_An_Evil_Practice_that_ Must_be_Stamped_Out (accessed 8 May2018).

11 Kok L, Boyle S, Lammers M, Tempelman C. Remuneration of medical specialists. Drivers of the differences between six European countries. Health Policy Amst Neth 2015; 119: 1188-1196.

12 Slemmer. Our nation cannot control runaway medical spending without fundamentally changing how physicians are paid. 2013; : 24.

13 Hanchak NA, Schlackman N, HarmonWeiss S. U.S. Healthcare's Quality-Based Compensation Model. Health Care Financ Rev 1996; 17: 143-159.

14 Bolotnikova MN. Are Hospital Pay-forPerformance Programs Failing? | Harvard Magazine.

2016.https: / / harvardmagazine.com/2016 /06/are-hospital-pay-for-performanceprograms-failing (accessed 8 May2018).

15 Mendes A, Lunkes RJ, Flach L, Kruger SD. The influence of remuneration on the behavior of hospital employees in Brazil. Contad Adm 2017; 62: 207-221.

16 Mendelson A, Kondo K, Damberg C, Low A, Motúapuaka $M$, Freeman $M$ et al. The Effects of Pay-for-Performance Programs on Health, Health Care Use, and Processes of Care: A Systematic Review. Ann Intern Med 2017; 166: 341.

17 Kementerian Kesehatan. Peraturan Menteri Kesehatan No. 27 tentang Petunjuk Teknis Sistem INA CBGs. 2014.http://www.jkn.kemkes.go.id/atta chment/unduhan/PMK\%20No.\%2027\%20tt 
g\%20Juknis\%20Sistem\%20INA\%20CBGs.pdf (accessed 14 Jul2019).

18 Darma $P$, Supriyanto A. THE EFFECT OF COMPENSATION ON SATISFACTION AND EMPLOYEES PERFORMANCE. Manag Econ $J$ MEC-J 2017; 1: 66.

19 Douven R, Mocking R, Mosca I. The effect of physician remuneration on regional variation in hospital treatments. Int $\mathrm{J}$ Health Econ Manag 2015; 15: 215-240.

20 Wright DJ. Specialist payment schemes and patient selection in private and public hospitals. J Health Econ 2007; 26: 10141026.

21 Campbell RJ. Change management in health care. Health Care Manag 2008; 27: 23-39.

22 Kabene SM, Orchard C, Howard JM, Soriano MA, Leduc R. The importance of human resources management in health care: a global context. Hum Resour Health 2006; 4: 20.

23 Kabene SM, Orchard C, Howard JM, Soriano MA, Leduc R. The importance of human resources management in health care: a global context. Hum Resour Health 2006; 4: 20.
24 Yaseen A. Effect of Compensation Factors on Employee Satisfaction- A Study of Doctor's Dissatisfaction in Punjab. Int $J$ Hum Resour Stud 2013; 3: 142.

$25 \mathrm{Mj} \mathrm{Z}$. The Influence of Income Level and Remuneration Schame on Jobsatisfaction. 2018; Volume Special (2): 128-134.

26 Kok L, Boyle S, Lammers M, Tempelman C. Remuneration of medical specialists. Drivers of the differences between six European countries. Health Policy Amst Neth 2015; 119: 1188-1196.

27 Phanthunane P, Pannarunothai S, Pagaiya N. REQUIREMENT AND SUPPLY PROJECTION OF SELECTED MEDICAL SPECIALISTS IN THAILAND IN 202. 2017; 17: 10

28 Bardey D, Cremer H, Lozachmeur J-M. Doctors' Remuneration Schemes and... (PDF Download Available). 2012.https: / /www.researchgate.net/pub lication/286555787_Doctors'_Remunerati on_Schemes_and_Hospital_Competition_i n_a_Two-Sided_Market (accessed 8 May2018).

29 OECD. Remuneration of doctors (general practitioners and specialists). 2015; : 8889. 